\title{
Peculiarities of Language Personality Structuring
}

\author{
Vasylieva Olena \\ Chernihiv Taras Shevchenko National Teacher's Training University, \\ Germanic Philology Department, PhD in Philology, Associate Professor, Ukraine
}

\begin{abstract}
The article deals with the peculiarities of the language personality (LP) structuring. The LP is viewed as a generalized image of the language speaker who uses the language as a means of nationally specific knowledge representation. The author classifies the factors which influence the LP formation and elaborates its level-and-component model as a system of four strata each combining a psychophysical and social component.
\end{abstract}

Keywords: language personality; communication; emotions; knowledge; vocabulary; level-and-component model of language personality.

UDC 81'44.111

LCC Subject Category: P1-1091

DOI: http://dx.doi.org/10.22178/pos.17-8

\section{Introduction}

Cognitive, sociological and cultural tendencies prominent in today's anthropocentric linguistics presuppose a thorough investigation of the language personality (LP) as a path through the central linguistics problem of speech presentation of the self. This conditions the topicality of the paper which focuses on the peculiarities of structuring the LP as a linguistic model used in both individual and group LPs studies. The tasks set in this investigation are to construe the term linguistic personality and summarize the structural peculiarities of LP in its level-and-component model.

\section{Review of Literature}

In language studies, cultural linguistics, psychology and methodology of language teaching, the LP has been scrutinized by Yu. M. Karaulov [1], S. G. Vorkachov [2], V. I Karasik [3], V. V. Krasnykh [4], V. A. Maslova [5], S. M. Avramenko [6] etc. In their researches LP is viewed as a generalized image of the self with a lingual mind, ethnic lingual worldview, language knowledge and skills, language norms and tastes, language practice and trends. As an abstract model of an ethnic lingual mind it finds its realization in LPs of the representatives of the language community, who use universal and nationally specific data to shape their individual speech style. This brings forward the necessity of an in-depth LP study aiming at understanding of the impact the person makes on the language and discourse.

\section{Research Methodology}

The methods used to gain the goal are general scientific methods of analysis and synthesis, as well as a deductive method, modelling in particular. The analysis was employed in singling out the components of the LP, which were synthesized to form a system of different levels of two components each. This was presented in the paper as a level-and-component model of the LP.

\section{Results and Discussion}

In the definition by Yu.M. Karaulov, LP is an individual who presents themselves in the language and with the help of the language, and therefore can be reconstructed through the analysis of the language means they use $[1$, c. 38]. It consists of three levels: the verbal one, which reflects the ability to use a layman's language, the cognitive one, which is where notions relevant for the community (and the person as a member of this community) are retrieved and processed to form the individual cognitive space and the pragmatic (conative) one, responsible for the identification of the goals and motives modelling the LP [1, p. 238; 6, p. 138].

So, the LP is a multilevel system of psychophysical qualities of the person speaking. It manifests 
itself in real communication; and it is personal interaction where national and individual peculiarities of the LP reveal themselves.

Taking into consideration the spheres of speakers interaction, V. V. Krasnykh singles out several aspects of LP [4, p. 22]:

1. LP proper, the personality in possession of knowledge and views, and manifesting itself in language performance.

2. Speech personality, the personality that reveals itself in communication choosing tools for putting a necessary interaction strategy into execution.

3. Communicative personality, a definite participant of the live communication act.

The above mentioned affords ground for elaboration of component structure of LP that reveals itself in communication as a set of the following constituents [5, p. 119]:

- axiological component (mindset, an aspect of education), that is a system of values, or life principles. The language provides both a spontaneous and thoughtful judgment of the world, creates the image of the world and forms the hierarchy of nonmaterial landmarks that underlie national character and drive national communication;

- personal component, embracing individual, intrinsic traits, which form the individuum;

- cultural component, the degree of culture exploration and internalization. When we acquire the standards of elocution involved in lingual and extralingual behavior, we develop survival skills and gain effective tools of influence on the communicants.

Thus, any LP feeds on information, which includes norms and concepts a definite person acquires with the language, accumulating knowledge produced by the humankind. The information the subject gets out of their psychophysical experiences and the social knowledge extracted from a particular culture create the environment necessary for the formation of different LP layers superimposed on biological and mental understrata (Table 1).

It becomes clear that the LP formation is to be a complex process of knowledge internalization and communication skills progression. It is considered to be affected by three factors, namely: the social one (as the personality is the core as well as the result of social regularities); the nationally specific one (as the personality is the product of the diachronic changes in the ethnic group), and the psychological one (as its pragmatic propensities appear when bodily needs, social and natural environment are balanced to the person's psyche) [6, p. 140].

Table 1 - Factors responsible for LP formation

\begin{tabular}{|l|l|l|}
\hline \multirow{2}{*}{ Level } & \multicolumn{1}{|c|}{$\begin{array}{c}\text { Domachophysical } \\
\text { faculty }\end{array}$} & $\begin{array}{c}\text { social } \\
\text { environment }\end{array}$ \\
\cline { 2 - 3 } Verbal & $\begin{array}{l}\text { A physical capacity } \\
\text { to articulate sounds, } \\
\text { psychology }\end{array}$ & $\begin{array}{l}\text { Language as a } \\
\text { semiotic system }\end{array}$ \\
\hline Cognitive & $\begin{array}{l}\text { A capacity for } \\
\text { cognition, which is } \\
\text { supported by the } \\
\text { reain facilitating }\end{array}$ & $\begin{array}{l}\text { Culture as a } \\
\text { social stock of } \\
\text { knowledge }\end{array}$ \\
\hline Conative & $\begin{array}{l}\text { Bodily needs of the } \\
\text { person }\end{array}$ & $\begin{array}{l}\text { Social needs of } \\
\text { the member of } \\
\text { the language } \\
\text { community }\end{array}$ \\
\hline
\end{tabular}

The latter explains why the researchers enrich the LP's structure with the emotional integrant, which is represented by the gradual transformation of emotions going along with the development of the LP: first they are biological emotions, which manifest satisfaction or dissatisfaction of the language need as a vital means of adjusting the body to the natural and social environment; later appear social emotions, which express your estimation of how the language is used by the people around you and consequently the degree of satisfaction or dissatisfaction caused; and finally, we deal with psychological emotions, which are the outcome of the estimation of yourself as a language speaker and their cultural environment together with the attitude towards the language as the sense born in actualization and validation of the nation through the development of the speech culture of the self [7, p. 127].

Taking into consideration the fact that reasons for activities grow thick and fast out of the person's needs, which reveal the current state of affairs, we see it necessary to single out in the LP the sensory-emotional level as a basic one in relation to the conative one. 
A synthesis of the suggested approaches to structuring the LP and the factors facilitating the LP formation results in modeling the LP as a system of the following strata:

- verbal level (the facet manifesting the LP as a human being that can speak);

- cognitive level (the knowledge the person has);
- conative level (the area where needs and wants which stimulate communication form);

- the sensory-emotional level (the level of perception and emotions that provoke needs and wants as a response).

On each stratum two components are distinguished - psychophysical and social (Table 2).

Table 2 - Level-And-Component Structure of LP

\begin{tabular}{|c|c|c|}
\hline \multirow{2}{*}{ Level } & \multicolumn{2}{|c|}{ Component } \\
\hline & psychophysical & social \\
\hline Verbal & Articulation basis & $\begin{array}{l}\text { Language as system of conventional } \\
\text { signs and the rules of their composition } \\
\text { and use }\end{array}$ \\
\hline Cognitive & $\begin{array}{l}\text { Self-directed knowledge of the world necessary } \\
\text { for orientation and survival of the individuum in } \\
\text { the environment }\end{array}$ & $\begin{array}{l}\text { Group-directed knowledge including } \\
\text { values and norms necessary for per- } \\
\text { sonal interaction }\end{array}$ \\
\hline Conative & Bodily needs, practical spurs & $\begin{array}{l}\text { Wants connected with self- } \\
\text { actualization in the society }\end{array}$ \\
\hline $\begin{array}{l}\text { Sensory- } \\
\text { emotional }\end{array}$ & Perception and biological emotions, psyche & Social and psychological emotions \\
\hline
\end{tabular}

\section{Conclusion}

The LP is any person who uses a language not only as a system of lingual rules but first of all as a means of nationally specific knowledge representation. The LP develops on four levels, the basic level being the sensory-emotional one. Each level combines biological and social components and is affected by different internal and external factors. The elaborated level-component model of LP may be used as a limitation factor in studies of LPs of particular languages users.

\section{References}

1. Karaulov, Yu.N. (2010). Russkii jazyk i yazykovaia lichnost [Russian Language and Language Personality]. Moscow: LKI Publishers (in Russian).

2. Vorkachev, S. G. (2001). Lingvokulturologiia, yazykovaia lichnost, kontsept : stanovleniie antropocentricheskoi paradigmy $\mathrm{v}$ yazykoznanii [Linguoculturology, Language Personality, Concept : Formation of Anthropocentric Paradigm in Linguistics]. Filologicheskiie nauki, 1, 64-72 (in Russian).

3. Karasik, V. I. (2002). Yazykovoi krug: lichnost, kontsepty, diskurs [Language Circle: Personality, Concepts, Discourse]. Volgograd: Peremena (in Russian).

4. Krasnykh, V.V. (2002). Etnopsikholingvistika i lingvokulturologiia [Ethnopsycholinguistics and Linguoculturology]. Moscow: Gnozis (in Russian).

5. Maslova, V. A. (2001). Lingvokulturologiia [Linguoculturology]. Moscow: Academiia Publishers (in Russian).

6. Avramenko, S. (2010). Movlennieva osobystist maibutnioho vchytelia v aspecti tolerantnosti [Speech Personality of Future Teacher in Terms of Tolerance]. Problemy Pidhotovky Suchasnoho Vchytelya, 2, 138-143 (in Ukrainian).

7. Zasiekina, L. (2004). Psykhosemantychni doslidzhennia motyvatsii [Psychosemantic Studues of Conation]. In Movna osobystist v suchasnomu sotsialnomu prostori (pp. 127-128). Kyiv: Akademiia (in Ukrainian).

(C) 0. Vasylieva 


\title{
Особенности структурирования языковой личности
}

\author{
Васильева Елена Григорьевна \\ Черниговский национальный педагогический университет имени Т.Г. Шевченко, \\ кафедра германской филологии, кандидат филологических наук, доцент, Украина
}

\begin{abstract}
Аннотация. Статья посвящена особенностям структурирования языковой личности, которая трактуется как обобщенный образ человека, пользующегося языком как национально специфическим инструментом для репрезентации знаний. Автор систематизирует факторы, влияющие на формирование языковой личности, и разрабатывает ее уровнево-компонентную модель в виде системы четырех уровней, каждый из которых включает психофизический и социальный компоненты.
\end{abstract}

Ключевые слова: языковая личность; коммуникация; эмоции; знания; вокабуляр; уровневокомпонентная модель языковой личности.

УДК 81'44.111

LCC Subject Category: P1-1091

DOI: http://dx.doi.org/10.22178/pos.17-8

\section{Список информационных источников}

1. Караулов Ю.Н. Русский язык и языковая личность. Москва : ЛКИ, 2010. 264 с.

2. Воркачев С.Г. Лингвокультурология, языковая личность, концепт: становление антропоцентрической парадигмы в языкознании. Филологические науки. 2001. № 1. С. 6472.

3. Карасик В. И. Языковой круг : личность, концепты, дискурс. Волгоград : Перемена, 2002. 477 с.

4. Красных В. В. Этнопсихолингвистика и лингвокультурология. Москва : Гнозис, 2002. 284 с.

5. Маслова В. А. Лингвокультурология. Москва : Академия, 2001. 208 с.

6. Авраменко С. Мовленнєва особистість майбутнього вчителя в аспекті толерантності. Проблеми підготовки сучасного вчителя. 2010. № 2. С. 138-143.

7. Засєкіна Л. Психосемантичні дослідження мотивації. Мовна особистість в сучасному соціальному просторі. Київ : Академія, 2004. С. 127-128.

(C) Е. Васильева

Статья получена 28.11.2016, принята 10.12.2016, опубликована оnline 13.12.2016 